Ю. І. Фещенко ${ }^{1,2}$, В. К. Гаврисюк ${ }^{1}$, Г. Л. Гуменюк ${ }^{2}$, Є. О. Меренкова ${ }^{1}$, Я. О. Дзюблик ${ }^{1}$, С. В. Зайков ${ }^{2}$ Н. А. Власова ${ }^{1}$

ДУ «Національний інститут фттизіатрії і пульмонології імені Ф. Г. Яновського НАМН Украӥни» ${ }^{1}$ Начіональна медична академія післядипломної освіти імені П. Л. Шупика МОЗ України ${ }^{2}$

\title{
ПЕРСОНІФІКОВАНИЙ ПІДХІД ДО ЛІКУВАННЯ САРКОЇДОЗУ ЛЕГЕНЬ
}

\author{
Персоніфікований підхід до лікування саркоїдозу \\ легень \\ Ю. І. Фещенко ${ }^{1,2}$, В.К. Гаврисюк', Г. Л. Гуменюк², \\ Є. О. Меренкова ${ }^{1}$, Я. О. Дзюблик ${ }^{1}$, С. В. Зайков ${ }^{2}$, \\ Н. А. Власова ${ }^{1}$ \\ ДУ «Національний інститут фртизіатрії \\ і пульмонології імені Ф. Г. Яновського НАМН \\ України» ${ }^{1}$ \\ Національна медична академія післядипломної освіти \\ імені П. Л. Шупика МОЗ України²
}

Резюме. Протягом багатьох років основними препаратами для лікування саркоїдозу залишаються глюкокортикостероїди (ГКС). У середньому близько 50 \% хворих на саркоїдоз (від 30 до 80 \%) лікуються 3 використанням ГКС. У випадках резистентності, наявності протипоказань або серйозних побічних ефектів ГКС-терапії, призначають препарати другої лінії, основне місце серед яких займають імуносупресанти. Необхідно зазначити, що і в прочесі терапії можуть спостерігатися різні варіанти перебігу захворювання, при цьому не існує критеріїв прогнозу регресії, стабілізації та прогресування саркоїдозу. У зв'язку з цим єдиним правильним принципом ведення хворих є персоніфрікований підхід до терапії.

Мета дослідження - розробити алгоритм персоніфрікованої терапії хворих на саркоїдоз на основі вивчення частоти протипоказань до призначення, серйозних побічних дій і випадків резистентності до глюкокортикостероїдів, визначення оптимального препарату імуносупресивної терапії.

Матеріали і методи. Обстежено 185 хворих на вперше виявлений саркоїдоз з ураженням паренхіми легень. У дослідження включили пацієнтів тільки на вперше виявлений саркоїдоз без будь-якої попередньої специфрічної терапії; другим, важливим критерієм відбору, була відсутність КT-ознак інтерстиціального фріброзу легень. Усім хворим проводили комп'ютерну томографрію органів грудної порожнини та оцінювали стан фуннкції зовнішнього дихання на основі аналізу даних спірометрії, бодіплетизмограсрії, дослідження дифрузійної здатності легень.

Результати. Отримані результати дають підставу вважати «Метотрексат» препаратом вибору в лікуванні хворих на саркоїдоз легень з протипоказаннями до призначення або серйозними побічними ефектами глюкокортикостероїдів. На підставі отриманих результатів (๖Ю. І. Фещенко та ін., 2020

ISSN 2706-6282(print) ISSN 2706-6290(online)

\section{Personified approach to treatment of pulmonary sarcoidosis}

Yu. I. Feshchenko ${ }^{1,2}$, V. K. Havrysiuk ${ }^{1}$, H. L. Humeniuk ${ }^{2}$, Ye. O. Merenkova ${ }^{1}$, Ya. O. Dziubluk ${ }^{1}$, S. V. Zaikov ${ }^{2}$, N. A. Vlasova ${ }^{1}$

F. Yanovskyi National Institute of Phthisiology and Pulmonology 1

P. Shupyk National Medical Academy of Postgraduate Education $^{2}$

e-mail: admin@ifp.kiev.ua

Summary. For many years, the main drugs for the treatment of sarcoidosis remain glucocorticosteroids. On average, about $50 \%$ of patients with sarcoidosis (from 30 to $80 \%$ ) are treated with corticosteroids. In cases of resistance, contraindications or serious side effects of corticosteroid therapy, second-line drugs are prescribed, the main place among which is held by immunosuppressants. It should be noted that in the course of therapy there may be different variants of the disease, and there are no criteria for the prognosis of regression, stabilization and progression of sarcoidosis. In this regard, the only correct principle of patient management is a personalized approach to therapy.

The aim of the study - to develop an algorithm for personalized therapy of patients with sarcoidosis based on the study of the frequency of contraindications, serious side effects and cases of resistance to glucocorticosteroids, to determine the optimal drug for immunosuppressive therapy.

Materials and Methods. 185 patients with newly diagnosed sarcoidosis with lesions of the lung parenchyma were examined. The study included patients only for newly diagnosed sarcoidosis without any prior specific therapy. The second, important selection criterion was the absence of computed tomography (CT) signs of interstitial pulmonary fibrosis. All patients underwent CT of the thoracic cavity and assessment of lung function (spirometry, bodyplethysmography, diffusion capacity of the lungs).

Results. The obtained results give grounds to consider methotrexate as the drug of choice in the treatment of patients with pulmonary sarcoidosis with contraindications or serious side effects of glucocorticosteroids. Based on the results, an algorithm for personalized therapy of patients with pulmonary sarcoidosis was developed, which considered the contraindications, serious side effects of 
розроблено алгоритм персоніфрікованої терапії хворих на саркоїдо легень, заснований на урахуванні протипоказань до призначення, серйозних побічних ефректів ГКС і резистентності до ГКС-терапії, застосуванні в якості імуносупресивної терапії метотрексату, що відрізняється оптимальним рівнем ефективності і профрілем безпеки.

Висновки. Застосування даного алгоритму терапіі дозволяє досягти клінічного вилікування в абсолютноі більшості хворих на саркоїдоз легень.

Ключові слова: саркоїдоз легень; лікування; алгоритм персоніфрікованої терапії.

\section{ВСТУП}

Саркоїдоз - мультисистемне захворювання невідомої природи, що характеризується утворенням в уражених органах неказеозних епітеліоїдноклітинних гранульом [1]. В останні роки спостерігається збільшення захворюваності на саркоїдоз в усьому світі, у тому числі й в Україні [2].

Зазвичай, саркоїдоз вражає людей молодого та середнього віку і часто проявляється двобічною лімфраденопатією коренів легень, дисемінацією паренхіми легень, ураженням очей і шкіри. Також можуть бути залучені печінка, селезінка, інші групи лімфратичних вузлів, слинні залози, серце, нервова система, м'язи, кістки й інші органи.

Саркоїдоз належить до групи імунозалежних захворювань. Саркоїдні гранульоми являють собою скупчення активованих клітин моноцитарномакрофрагального ряду, а також розвиваються в умовах запалення гігантських багатоядерних клітин, епітеліоїдних клітин і лімсроцитів [3].

у більшості випадків саркоїдозу з ураженням паренхіми легень потрібне медикаментозне лікування, оскільки спонтанна регресія процесу спостерігається тільки у 30 \% пацієнтів [4]. Однак необхідно зазначити, що і в процесі терапії можуть спостерігатися різні варіанти перебігу захворювання, при цьому не існує критеріїв прогнозу регресії, стабілізації та прогресування саркоїдозу. У зв'язку з цим єдино правильним принципом ведення хворих є персонісрікований підхід до терапії.

Основною причиною розвитку прогресуючого перебігу саркоїдозу і незадовільних результатів лікування $€$ резистентність до традиційної терапії глюкокортикостероїдами (ГКС), протипоказання до ії̈ проведення, серйозні побічні дії ГКС $[5,6]$. Однак у літературі відсутні відомості про частоту протипоказань, серйозних побічних дій і випадків резистентності до ГКС-терапії у хворих на вперше виявлений саркоїдоз з ураженням паренхіми легень, у зв'язку з чим не відомі істинні показники есрективності ГКС-терапії, а також не встановлена реальна потреба в імуносупресивній терапії.

У випадках резистентності, наявності протипоказань або серйозних побічних есректів ГКСтерапії призначаються препарати другої лінії, осно- corticosteroids and resistance to corticosteroid therapy, utilizing the immunosuppressive therapy with methotrexate due to its optimal level of efficacy and safety profile.

Conclusions. The use of this algorithm of therapy allows achieving clinical cure in the vast majority of patients with pulmonary sarcoidosis.

Key words: pulmonary sarcoidosis; treatment; algorithm of personified therapy.

вне місце серед яких займають імуносупресанти - «Азатіоприн», «Лесрлуномід», «Метотрексат» [7-9]. Разом із тим, відсутні дані про порівняльну характеристику ефективності й переносимості цих препаратів у хворих на саркоїдоз.

Все це зумовило необхідність вивчити і провести порівняльний аналіз ефективності та частоти побічних дій азатіоприну, лесрлуноміду і метотрексату у хворих із протипоказаннями до призначення або серйозними побічними діями ГКС з метою визначення оптимального препарату імуносупресивної терапії хворих на саркоїдоз легень.

Метою дослідження було розробити алгоритм персонісрікованої терапії хворих на саркоїдоз на основі вивчення частоти протипоказань до призначення, серйозних побічних дій і випадків резистентності до глюкокортикостероїдів, визначення оптимального препарату імуносупресивної терапії.

\section{МАТЕРІАЛИ I МЕТОДИ}

Обстежено 185 хворих на вперше виявлений саркоїдоз з ураженням паренхіми легень. Чоловіків було 80 (43,2 \%), жінок - 105 (56,8 \%) у віці від 20 до 67 років $((42,3 \pm 0,8)$ року). II стадію захворювання було встановлено у $173(93,5$ \%) хворих, III стадію - у 12 (6,5\%).

Діагноз саркоїдозу був верифрікований методом КТ органів грудної порожнини (ОГП), виконаної на KT-сканері Aquilion TSX-101A (Toshiba). Стан суункції зовнішнього дихання оцінювали на основі аналізу даних спірометрії, бодіплетизмографії, дослідження дифрузійної здатності легень на спірометричній системі MasterScreen («Viasys Healthcare $\mathrm{GmbH»)} \mathrm{з} \mathrm{відповідними} \mathrm{модулями.}$

При відборі хворих строго дотримувалися двох принципів: по-перше, в дослідження включали пацієнтів тільки із вперше виявленим саркоїдозом без будь-якої попередньої специфрічної терапії; подруге, важливим критерієм відбору, що дозволяє 3 максимальною можливістю виключити хворих із довгостроково поточним процесом, була відсутність КТ-ознак інтерстиціального фріброзу легень. Дослідження виконане за кошти держбюджету. 


\section{РЕЗУЛЬТАТИ Й ОБГОВОРЕННЯ}

Протипоказаннями до призначення ГКС $€$ : алергія до синтетичних стероїдів, цукровий діабет, остеопороз, переломи, асептичний некроз кісток, тяжка артеріальна гіпертензія, глаукома, виразкова хвороба шлунка та дванадцятипалої кишки, тромбофрлебіти, системні мікози, хронічна гнійна інфрекція, туберкульоз, вірусні інфекції, системний мікоз, психічні захворювання, синдром Кушинга, тромбоемболічний синдром [1].

У момент встановлення діагнозу протипоказання до призначення ГКС були виявлені у $23(12,4$ \%) пацієнтів: гіпертонічна хвороба в поєднанні 3 ожирінням - у 9 осіб, цукровий діабет 2 типу - в 7, ожиріння II-III ступенів (індекс маси тіла >35 ) - у 6, виразкова хвороба шлунка - в 1. У зв'язку з цим в якості стартової терапії цим хворим була призначена імуносупресивна терапія.

До серйозних побічних дій, що вимагають відміни ГКС, відносяться: алергія до синтетичних стероїдів, остеопороз, переломи, асептичний некроз кісток, стероїдний діабет, стероїдні виразки шлунка і кишечника, шлунково-кишкові кровотечі, психози, симптоми менінгізму, ейфрорія, депресія, безсоння, стероїдний васкуліт, загострення хронічних інорекцій, у тому числі туберкульозу; приєднання вторинної інфекції, задня субкапсулярна катаракта, глаукома [1].

Глюкокортикостероїдну терапію метилпреднізолоном (МП) проводили з використанням схеми, розробленої в Національному інституті фртизіатрії і пульмонології імені Ф. Г. Яновського НАМН України. Схема включена в Уніфікований клінічний протокол «Саркоїдоз» [10]. МП призначали в дозі 0,4 мг/ кг маси тіла протягом 4 тижнів (для хворого масою 60 кг доза препарату складе 24 мг на добу). Потім дозу знижують протягом 8 тижнів такими темпами, щоб до кінця третього місяця вона склала 0,2 мг/ кг. Через 3 місяці від початку лікування оцінювали його ефективність. При позитивній динаміці клінічних та рентгенологічних даних дозу препарату поступово знижують до 0,1 мг/кг до кінця 6-го місяця, протягом наступного періоду лікування дозу зберігають незмінною. Після досягнення клінічного вилікування з нормалізацією КТ-даних ГКС-терапія в дозі 0,1 мг/кг МП триває не менше 6 місяців.
Серйозні побічні дії ГКС розвинулися у 5 пацієнтів, що стало причиною відміни МП і призначення імуносупресивного препарату. В 4 хворих причиною відміни ГКС був остеопороз, причиною відміни ГКС у п'ятого пацієнта був розвиток цукрового діабету на тлі тривалого лікування МП.

Резистентність до ГКС-терапії підрозділяється на абсолютну і відносну. Абсолютна рел зистентність означає відсутність будь-якого позитивного ефекту при використанні адекватних доз препаратів і режимів терапії. Відносна резистентність до ГКС-терапії констатується у випадках прогресування або стабілізації процесу при зниженні дози МП до підтримувальної (0,1 мг/кг/добу) при наявності ознак регресії на етапах стартової терапії при використанні спочатку більш високих доз МП.

Резистентність до ГКС-терапії спостерігали у 32 хворих (17,3\%), при цьому в 9 пацієнтів відзначали абсолютну резистентність, у 23 - відносну. Всім пацієнтам із резистентністю були призначені препарати другої лінії.

У таблиці 1 представлено поділ хворих залежно від частоти протипоказань до призначення ГКС, серйозних побічних ефектів препаратів і випадків резистентності до ГКС-терапії.

Таким чином, ГКС-терапія, яку проводили упродовж не менше 12 місяців із досягненням клінічного одужання, підтвердженого даними КТ, була успішно завершена тільки у 125 хворих (67,6 \%). У 60 пацієнтів (32,4%), у зв'язку з протипоказаннями до призначення, серйозними побічними діями і резистентністю до лікування ГКС, була застосована імуносупресивна терапія, при цьому в 23 (12,4%) вона мала стартовий характер.

Таким чином, у середньому в кожного восьмого хворого на саркоїдоз II-III стадій $(12,4$ \%) потрібно призначати імуносупресивну терапію вже в момент встановлення діагнозу у зв'язку з наявністю протиу показань до застосування ГКС. У ході ГКС-терапії потреба в лікуванні імуносупресантами зростає у зв'язку з серйозними побічними ефектами препарату, а також з причини резистентності до ГКС-терапії у середньому до 32,4 \%. Тобто кожному третьому пацієнту на різних етапах лікування необхідно призначати імуносупресанти.

Таблиця 1. Протипоказання до призначення або продовження ГКС-терапії у хворих на вперше виявлений саркоїдоз легень II-III стадій

\begin{tabular}{l|c|c}
\hline \multicolumn{1}{c|}{ Група хворих } & \multicolumn{2}{c}{ Кількість хворих } \\
\cline { 2 - 3 } & абс. & $\%$ \\
\hline Протипоказання до призначення ГКС & 23 & 12,4 \\
\hline Серйозні побічні есректи ГКС & 5 & 2,7 \\
\hline Резистентність до лікування ГКС & 32 & 17,3 \\
\hline Хворі з успішним завершенням курсу ГКС-терапії & 125 & 67,6 \\
\hline Усього пацієнтів із вперше виявленим саркоїдозом II-ІІІ стадій & 185 & 100 \\
\hline
\end{tabular}

ISSN 2706-6282(print)

ISSN 2706-6290(online)
Вісник медичних і біологічних досліджень Bulletin of Medical and Biological Research
$4(6), 2020$ 
Еорективність і переносимість азатіоприну, лефлуноміду та метотрексату були вивчені у 40 хворих на саркоїдоз легень II стадії - 32 жінки і 8 чоловіків у віці від 31 до 69 років.

У 29 пацієнтів імуносупресивну терапію застосовували в якості стартової у зв'язку з наявністю протипоказань до призначення ГКС - гіпертонічна хвороба (9 пацієнтів), цукровий діабет 2 типу (12), ожиріння II-III ступенів (6), виразкова хвороба шлунка (1), психічні розлади (1). В 11 випадках імуносупресант був призначений унаслідок серйозної побічної дії попередньої ГКС-терапії - остеопорозу (7), стероїдного діабету (2), депресії та безсоння (2).

Монотерапіюазатіоприномпроводили10хворим. Препарат був призначений в дозі по 50 мг/добу 3 подальшим збільшенням дози на 25 мг/добу кожні 2 тижні до досягнення максимальної - 150 мг/добу. Перед початком терапії і щомісяця в процесі терапії проводили загальний аналіз крові 3 визначенням кількості тромбоцитів, визначали концентрацію АЛт, рівень білірубіну і креатиніну. Результати лікування оцінювали через 3 місяці з урахуванням клінічних, функціональних даних і результатів КТ.

В двох пацієнтів у процесі лікування азатіоприном в дозі 75 мг/добу розвинулися серйозні побічні ефекти, що потребували відміни препарату: в одному випадку - лейкоцитопенія (3,5×10\%/л) і тромбоцитопенія $(90 \times 10 \%)$, у другому випадку - збільшення вмісту АЛТ (147 од./л), що більш ніж в 3 рази перевищувало норму, і лейкоцитопенія (3,0×10\%/л). Після нормалізації гемограми і вмісту АЛТ в крові хворим призначали терапію метотрексатом.

У 2 випадках через 3 місяці терапії азатіоприном спостерігали регресію саркоїдозу зі зменшенням щільності вузликової дисемінації у легенях за результатами КТ. Хворим було рекомендовано продовжувати лікування зі щомісячним контролем гемограми, вмісту трансаміназ і білірубіну в крові.

У 6 пацієнтів на тлі лікування азатіоприном розвинулося виражене прогресування саркоїдозу - значне збільшення щільності вузликової дисемінації у легенях за даними КТ.

3 огляду на високу частоту прогресування захворювання на тлі лікування азатіоприном, по- дальше включення хворих у дослідження ефективності препарату було припинено.

Монотерапія лефрлуномідом 11 хворих $з$ протипоказаннями до призначення або серйозними побічними ефектами ГКС була успішною у 4 з 11 пацієнтів, у 2 хворих спостерігалася стабілізація процесу, в 1 випадку лікування було припинено через серйозні побічні ефекти препарату (виражена пірогенна реакція, збільшення АлТ, що більш ніж в 3 рази перевищувало норму) та у 4 пацієнтів на тлі терапії лефрлуномідом відзначалося прогресування захворювання.

Терапію метотрексатом в дозі 10 мг 1 раз на тиждень проводили 19 пацієнтам із саркоїдозом легень. У 16 хворих терапію метотрексатом застосовували в якості стартової у зв'язку з нав явністю протипоказань до призначення ГКС, у 3 випадках метотрексат був призначений унаслідок серйозної побічної дії попередньої ГКС-терапії.

Через 3 місяці терапії метотрексатом у більшості пацієнтів (14-73,7 \%) спостерігалися ознаки регресії саркоїдозу, в 4 випадках відзначена стабілізація процесу, в 1 пацієнта було прогресування - збільшення поширеності й щільності вузликової дисемінації у паренхімі. Лікування хворих зі стабілізацією було продовжено як раніше, у хворого 3 прогресуванням дозу метотрексату було збільшено до 15 мг/тиждень.

У таблиці 2 представлені результати порівняльного вивчення ефективності та переносимості азатіоприну, лефрлуноміду та метотрексату у хворих на саркоїдоз легень із протипоказаннями до призначення або серйозними побічними ефектами глюкокортикостероїдів.

Отримані результати дають підставу вважати метотрексат препаратом вибору в лікуванні хворих на саркоїдоз легень 3 протипоказаннями до призначення або серйозними побічними ефектами глюкокортикостероїдів.

На основі отриманих результатів розроблено алгоритм персонісрікованої терапії хворих на саркоїдоз легень (рис.), заснований на урахуванні протипоказань до призначення, серйозних побічних есректів ГКС і резистентності до ГКС-терапії, застосуванні в якості імуносупресивної терапії

Таблиця 2. Ефективність і переносимість азатіоприну, лефлуноміду та метотрексату у хворих на саркоїдоз легень із протипоказаннями до призначення або серйозними побічними ефектами ГКС (3 місяці терапії)

\begin{tabular}{l|c|c|c|c|c|c}
\hline \multirow{2}{*}{ Результат лікування } & \multicolumn{2}{c|}{$\begin{array}{c}\text { Азатіоприн } \\
(\mathrm{n}=10)\end{array}$} & \multicolumn{2}{c|}{$\begin{array}{c}\text { Лесрлуномід } \\
(\mathrm{n}=11)\end{array}$} & \multicolumn{2}{c}{$\begin{array}{c}\text { Метотрексат } \\
(\mathrm{n}=19)\end{array}$} \\
\cline { 2 - 8 } & абс. & $\%$ & абс. & абс. & абс. & \% \\
\hline Регресія & 2 & 20,0 & 4 & 36,6 & 14 & 73,7 \\
\hline Стабілізація & - & - & 2 & 18,2 & 4 & 21,1 \\
\hline Прогресування & 6 & 60,0 & 4 & 36,4 & 1 & 5,2 \\
\hline $\begin{array}{l}\text { Відміна препарату у зв'язку з серйозним } \\
\text { побічним ефректом }\end{array}$ & 2 & 20,0 & 1 & 9,0 & - & - \\
\hline
\end{tabular}




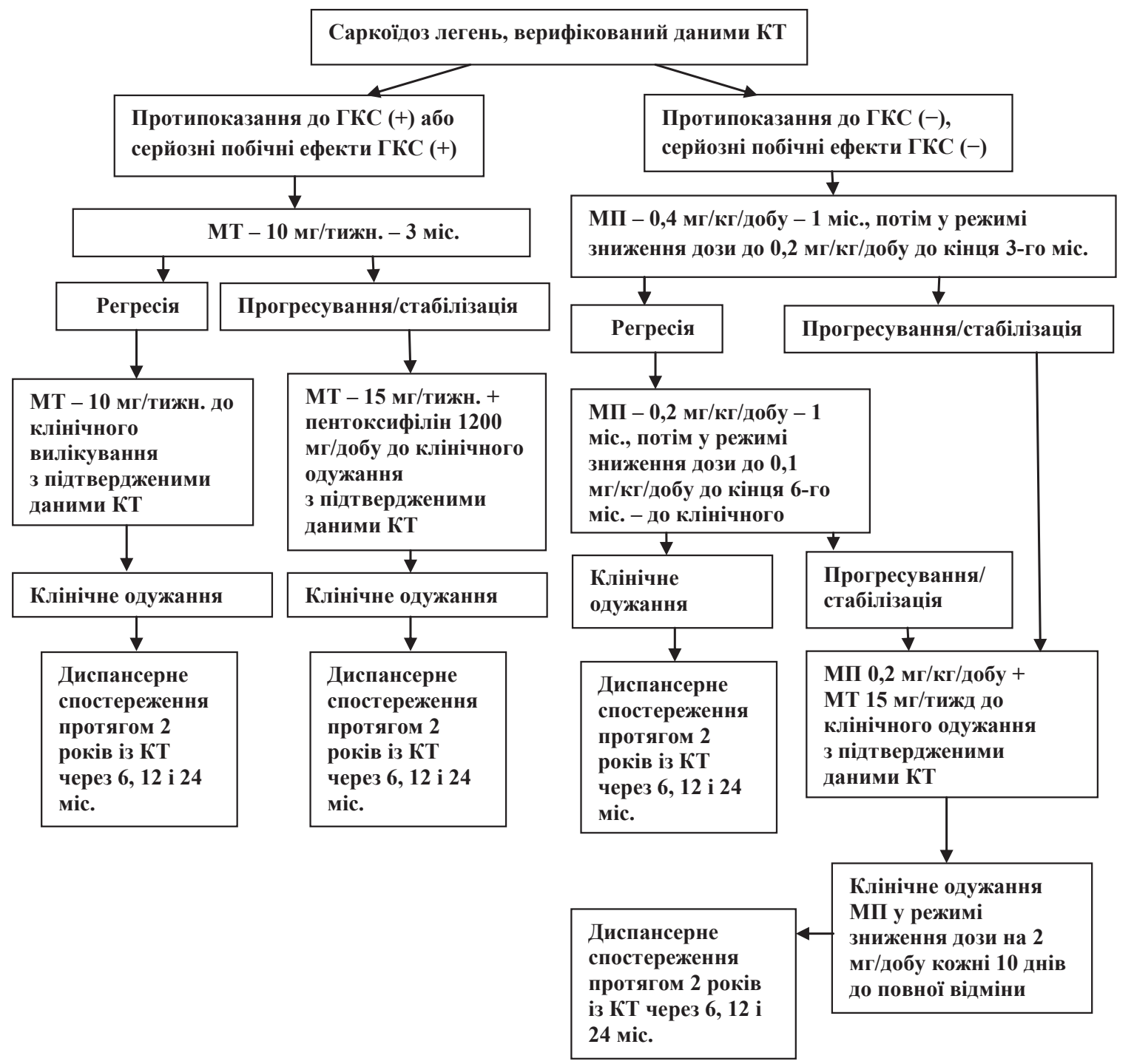

Рис. Алгоритм терапії хворих на саркоїдоз легень.

Примітка. МП - метилпреднізолон, МТ - метотрексат.

метотрексату, що відрізняється оптимальним рівнем ефективності й профрілем безпеки.

\section{ВИСНОВКИ}

Застосування даного алгоритму терапії дозволяє досягти клінічного вилікування в абсолютної більшос-

\section{СПИСОК ЛІТЕРАТУРИ}

1. American Thoracic Society (ATS), European Respiratory Society (ERS), World Association of Sarcoidosis and Other Granulomatous Disoders (WASOG). Statement on Sarcoidosis // Am. J. Respir. Crit. Care Med. - 1999. Vol. 160. - P. 736-755. DOI: 10.1164/ajrccm.160.2.ats4-99.

2. Саркоидоз органов дыхания: эпидемиология, структура больных, результаты лечения / В. К. Гаврисюк [и др.] // Укр. терапевт. журн. - 2014. - № 2. - С. 95-100.

3. Gerke A. K. The immunology of sarcoidosis / A. K. Gerke, G. Hunninghake // Clin. Chest Med. - ті хворих на саркоїдоз легень. Однак необхідно зазначити, що у 5-7 \% пацієнтів спостерігається резистентність не тільки до ГКС-терапії, але і до лікування метотрексатом. У цих випадках необхідно застосовувати препарати третьої лінії, основним 3 яких є інгібітор фрактора некрозу пухлини- $\alpha$ «ннфлліксимаб».

2008. - Vol. 29, No. 3. - P. 379-390. DOI: 10.1016/j. ccm.2008.03.014.

4. Саркоидоз органов дыхания / ред. В. К. Гаврисюк. - K., 2015. - 192 c.

5. Baughman R. P. The treatment of pulmonary sarcoidosis / R. P. Baughman, M. Drent // Pulmonary sarcoidosis. - Judson M. A. ed. Humana Press - brand of Springer. - 2014. - P. 41-64.

6. Schutt A. C. Pharmacotherapy for pulmonary sarcoidosis: A Delphy consensus study / A. C. Schutt, 
W. M. Bullington, M. A. Judson // Respir. Med. - 2010. Vol. 104, No. 5. - P. 717-723. DOI: 10.1016/j. rmed.2009.12.009.

7. Korsten P. Refractory pulmonary sarcoidosis - proposal of definition and recommendation for the diagnostic and therapeutic approach / P. Korsten, K. Strohmayer, R. P. Baughman // Clin. Pulm. Med. - 2016. - Vol. 23, No. 2. - P. 67-75. DOI: 10.1097/CPM.0000000000000136.

8. Amin E. N. Current best practice in the management of pulmonary and systemic sarcoidosis / E. N. Amin, D. R. Closser, E. D. Crouser // Ther. Adv. Respir.

\section{REFERENCES}

1. American Thoracic Society (ATS), European Respiratory Society (ERS), World Association of Sarcoidosis and Other Granulomatous Disoders (WASOG). Statement on Sarcoidosis. Am J Respir Crit Care Med. 1999;160(2): 73655. DOI: 10.1164/ajrccm.160.2.ats4-99.

2. GavrysiukVK, Gumeniuk GL, MerenkovalO, IachnikAI, Dziublyk YO et al. [Pulmonary sarcoidosis: epidemiology, patient structure, treatment results]. Ukr terapevt zhurn. 2014;2: 95-100. Ukrainian.

3. Gerke AK, Hunninghake G. The immunology of sarcoidosis. Clin Chest Med. 2008;29(3): 379-90. DOI: 10.1016/j.ccm.2008.03.014.

4. Gavrysiuk VK. Pulmonary sarcoidosis. [Саркоидоз органов дыхания] Kyiv; 2015.. Ukrainian.

5. Baughman RP, Drent M. The treatment of pulmonary sarcoidosis. Pulmonary sarcoidosis. Judson MA. Editor. Humana Press - brand of Springer; 2014.

6. Schutt AC, Bullington WM, Judson MA. Pharmacotherapy for pulmonary sarcoidosis: A Delphy consensus
Dis. - 2014. - Vol. 8, No. 4. - P. 111-132. DOI: $10.1177 / 1753465814537367$

9. Baughman R. P. Methotrexate is steroid sparing in acute sarcoidosis: results of double blind, randomized trial / R. P. Baughman, D. B. Winget, E. E. Lower // Sarcoidosis Vasc. Diffuse Lung Dis. - 2000. - Vol. 17, No. 1. - P. 60-66. PMID: 10746262.

10. Унісрікований клінічний протокол первинної, вторинної (спеціалізованої) та третинної (високоспеціалізованої) медичної допомоги «Саркоїдоз» : наказ МОЗ України № 634 від 08.09.2014.

study. Respir Med. 2010;104(5): 717-23. DOI: 10.1016/j. rmed.2009.12.009.

7. Korsten P, Strohmayer K, Baughman RP. Refractory pulmonary sarcoidosis - proposal of definition and recommendation for the diagnostic and therapeutic approach. Clin Pulm Med. 2016;23(2): 67-75. DOI: 10.1097/ CPM.0000000000000136.

8. Amin EN, Closser DR, Crouser ED. Current best practice in the management of pulmonary and systemic sarcoidosis. Ther Adv Respir Dis. 2014;8(4): 111-32. DOI: $10.1177 / 1753465814537367$

9. Baughman RP, Winget DB, Lower EE. Methotrexate is steroid sparing in acute sarcoidosis: results of double blind, randomized trial. Sarcoidosis Vasc. Diffuse Lung Dis. 2000.17(1): 60-6. PMID: 10746262.

10. Unified clinical protocol of the first, second (special) and third (high-class) medical aid "Sarcoidosis". Order of the Ministry of Health of Ukraine No. 634 of September 8, 2014. Ukrainian. 